\title{
Unexpected volatility and intraday serial correlation*
}

\author{
Simone Bianco \\ Center for Nonlinear Science, University of North Texas \\ P.O. Box 311427, Denton, Texas, 76201-1427 \\ e-mail: sbianco@unt.edu \\ Roberto Renò \\ Dipartimento di Economia Politica, Università di Siena \\ Piazza S.Francesco 7, 53100, Siena \\ e-mail: reno@unisi.it
}

14th August 2021

\begin{abstract}
We study the impact of volatility on intraday serial correlation, at time scales of less than 20 minutes, exploiting a data set with all transaction on SPX500 futures from 1993 to 2001. We show that, while realized volatility and intraday serial correlation are linked, this relation is driven by unexpected volatility only, that is by the fraction of volatility which cannot be forecasted. The impact of predictable volatility is instead found to be negative (LeBaron effect). Our results are robust to microstructure noise, and they confirm the leading economic theories on price formation.
\end{abstract}

${ }^{*}$ We acknowledge participants at the IV Workshop LABSI, Siena, and Taro Kanatani for useful comments. SB thankfully acknowledges the Welch foundation for financial support through Grant no. B-1577. 


\section{Introduction}

The study of serial correlation in asset prices is of great importance in financial economics. Indeed, from the point of view of market efficiency Fama,

1970), as well as market inefficiency (Shleifer, 2003), serial correlation is a market anomaly which need to be addressed by economic theories. Once serial correlation is significantly detected in the data, see James (2003) as an example, an explanation is needed to reconcile the empirical finding with the assumption of informational efficiency of the market. This has been typically accomplished in a rational setting (Lo and MacKinlav, 1990; Boudoukh et al., 1994; Sentana and Wadhwani, 1992; Safvenvblad, 2000) or in a behavioral setting (Cutler et al., 1991; Jegadeesh and Titman, 1993; Chan, 1993; Badrinath et al., 1995; Challet and Galla, 2005). In this paper, we concentrate on very short-run serial correlation, that is we focus on intraday data and in particular on time scales from 4 to 20 minutes.

The purpose of this paper is multiple. Beyond showing the informational efficiency of the considered market, which is actually out of discussion given its liquidity, our aim is to study the dynamical properties of intraday serial correlation. We extend previous literature by decomposing intraday volatility, measured by means of realized volatility, into its predictable and unpredictable part. To quantify intraday serial correlation, we use the variance-ratio test on evenly sampled intraday data. While being very standard for daily data, the variance ratio test has still little application on high-frequency data, including Andersen et al. 2001); Thomas and Patnaik (2003); Kaul and Sapp (2005).

Our main result is that intraday serial correlation is positively linked with unexpected volatility, defined as the residual in a linear regression model for daily volatility as measured with intraday data. In other words, unexpected volatility is that part of volatility which was not forecasted on that market in that particular day. We also explain the puzzling results of Bianco and Renò (2006) who, on a much less liquid market (Italian stock index futures), found volatility to be positively correlated with serial correlation, at odds with the result in LeBaron 1992). We show that indeed total volatility is positively related to serial correlation: however, it is unexpected volatility that drives this positive relation. The predictable part of volatility, that used in LeBaron (1992), turns out to be negatively related to serial correlation, in agreement with previous literature.

The paper is organized as follows. Section 2 illustrates the methodology 
and describes the data set. Section 3 shows the estimation results and discusses the implications of them. Section 4 concludes.

\section{Data and methodology}

The data set under study is the collection of all transactions on the S\&P500 stock index futures from April, 1993 to October 2001, for a total of 1,975 trading days. We have information on all futures maturity, but we use only next-to-expiration contracts, with the S\&P 500 expiring quarterly. We use only transactions from $8: 30$ a.m. to $3: 15$ p.m.. In total, we have 4, 898, 381 transactions, that is 2,480 per day on average, with an average duration between adjacent trades of 9,8 seconds. Not all high-frequency information is used. We use instead a grid of evenly sampled data every day. We find that a time interval of $\Delta t=4$ minutes is a large enough to avoid the problem of intervals with no price changes within. Thus, for every day, we have a time series of 101 evenly sampled prices.

To study intraday serial correlation, we use the variance-ratio statistics. This briefly consists in what follows. Denote by $P_{k}, k=1, \ldots, N$ a time series and define the first differences time series $r_{k}=P_{k}-P_{k-1}$. The variance ratio at lag $q$ is given by

$$
\operatorname{VR}(q)=\frac{\operatorname{Var}\left[r_{k}(q)\right]}{\operatorname{Var}\left[r_{k}\right]}
$$

where

$$
r_{k}(q)=\sum_{j=1}^{q+1} r_{k+j}
$$

represents the $q$-period return. We implement the variance ratio test according to the heteroskedastic consistent estimator (Lo and MacKinlav, 1988) with overlapping observations (Richardson and Smith, 1993), for which the asymptotic distribution is well known under the null, see Appendix $\mathrm{A}$. In particular, Bianco and Reno (2006) show that the VR test can be implemented on high frequency data of stock index futures transactions, for time scales lower than 20 minutes, given the typical heteroskedasticity of this asset. This is in line with the robustness analysis of Deo and Richardson 2003). We then study values of $q$ ranging from 1 to 5 , since in our case the interval between adjacent observations is 4 minutes. For these values of $q$, we can then safely use the VR test with high-frequency data in our context. 
We then compute 1,975 daily values of the variance ratio for $q=1, \ldots, 5$. The top panel of table 1 reports the number of significantly positive and negative variance ratios, for different confidence intervals. The positive violations are compatible with the null. The excess in negative violations can instead be ascribed to the bid-ask bounce effect, see the thorough discussion in Bianco and Renò (2006).

In order to quantify the daily serial correlation, we use the standardized variance ratio at different lags $q$, defined as:

$$
\widetilde{V R}(q)=\sqrt{n q} \frac{\widehat{V R}(q)-1}{\sqrt{\hat{\theta}(q)}},
$$

where $\hat{\theta}(q)$ is the heteroskedastic consistent estimator of the variance ratio variance, see Appendix $\mathrm{A}$. The time series of variance ratios at $q=1$ is shown in figure 1

Given the high persistence in volatility, also the standardized variance ratio is found to be highly persistent. We discuss further this point in Section 3 .

We want to link serial correlation with volatility. On each day, in which we have $N$ returns, we define volatility as

$$
\sigma^{2}=\sum_{k=1}^{N} r_{k}^{2}
$$

This is the well-known measure of realized variance, see Andersen et al. (2003). However, in what follows we argue that an other variable plays a very special role, that is unexpected volatility. We know that volatility is highly foreseeable in financial markets, see Poon and Granger (2003) for a review, mainly given its persistence. Moreover, a simple linear model for realized volatility leads to fair forecasts, see e.g. Andersen et al. (2003); Corsi et al. (2001). We then assume that the market volatility is forecasted with the following linear model:

$$
\log \left(\sigma_{t}^{2}\right)=\alpha+\beta_{1} \log \left(\sigma_{t-1}^{2}\right)+\beta_{2} \log \left(\sigma_{t-2}^{2}\right)+\beta_{3} \log \left(\sigma_{t-3}^{2}\right)+\varepsilon_{t} .
$$

Even if the model [5] is fairly simple, since it ignores long-memory and leverage effects, on the US stock index futures data it yields an $R^{2}$ of $66.2 \%$. We then define unexpected volatility as the residuals of the above regression,

$$
\sigma_{u, t} \equiv \hat{\varepsilon}_{t}
$$



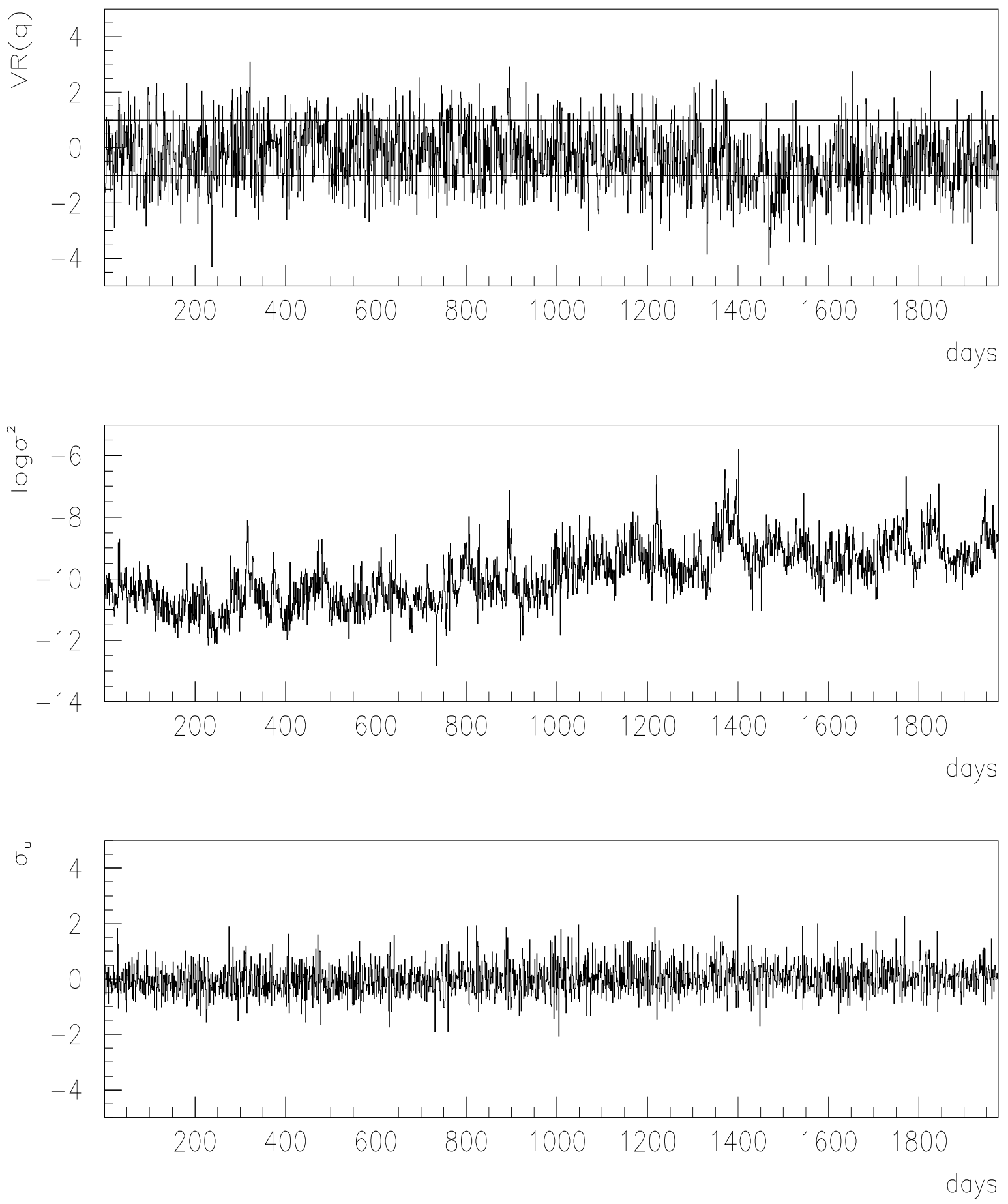

Figure 1: From top to bottom: the time series of $\widetilde{V R}(1)$ with one standard deviation bands, the daily realized volatility and the estimated unexpected volatility. 
We also define the predictable part of volatility, as:

$$
\sigma_{p, t} \equiv \log \left(\sigma_{t}^{2}\right)-\sigma_{u, t}
$$

By construction, lagged volatility at times $t-1, t-2, t-3$ and unexpected volatility are orthogonal. Thus $\sigma_{p, t}$ and $\sigma_{u, t}$ are orthogonal as well.

It is clear that our definition of unexpected and predictable volatility is dependent on model (5); however the inclusion of further lags does not change our results; and including more complicated effects does not improve the specification of model [5, see the extensive study of Hansen and Lunde 2005). Also nonlinear specifications, as those of Maheu and McCurdv (2002), have been found to yield forecast improvements which are not substantial.

\section{Results}

We start from the finding in Bianco and Renò (2006) that standardized variance ratios are negatively autocorrelated, and we confirm this finding on US data. However, this feature is inherited by the serial auto-correlation of the volatility itself. To check this, we simulate a long series of a $\operatorname{GARCH}(1,1)$ process with zero auto-correlation. On the simulated series we spuriously detect an autocorrelated standardized variance ratio. Since the simulated series is persistent, we conclude that the serial correlations of the standardized VRs is a consequence of the heteroskedasticity of the data. However, in order to get reliable specification when the variance ratio is the dependent variable, it is necessary to add lagged variance ratio regressors as explanatory variables.

As an overall specification test for the regression, we use the Ljung-Box test of residuals at lag 5 and we denote it by $Q(5)$. We first study a model in which we include volatility as a regressor:

$$
\widetilde{V R}_{t}=\alpha+\sum_{i=1}^{4} \delta_{i} \widetilde{V R}_{t-i}+\beta \cdot \log \left(\sigma_{t}^{2}\right)+\varepsilon_{t}
$$

Results are in Table 2, We find that there is a positive and significant relation between volatility and standardized variance ratio, and the regression is well specified if we include enough autoregressive terms for the variance ratio, see the Ljung-Box statistics. This result is not entirely surprising. On a much smaller market (Italy), Bianco and Renò (2006) provide evidence of a positive relation between volatility and intraday serial correlation. This is 
different from what is typically found at daily level, where the correlation is found to be negative, according to the LeBaron effect (LeBaron, 1992; Sentana and Wadhwani, 1992). However, this result can be explained according to the model of reinforcement of opinions of Chan 1993). According to this model, serial correlation is introduced into data since once an investor decides to buy, he observes more liquid substitutes and reinforce his opinion according to the movements of the substitutes. This effect is stronger when volatility is high, that is when the price move more (or more rapidly). Thus, the Chan (1993) model posits a positive relation between volatility and intraday serial correlation which is at all reasonable. However, for the US market the Chan model is less tenable. Indeed, for the US it is unreasonable to look for a more liquid substitute. Thus, the effect of the reinforcement of opinions is likely to be milder. To better understand this, we compute the percentage of significant VRs as volatility increases. The violations are reported in Table 1, On the contrary on what happens on the Italian market, where the percentage of positive violations increases when volatility increases, we find that this holds marginally for the US market, confirming our intuition that the mechanism of reinforcement of opinions is likely to play a minor role in a liquid market as the US stock index futures.

We then analyze the impact of unexpected volatility. We estimate the regression:

$$
\widetilde{V R}_{t}=\alpha+\sum_{i=1}^{4} \delta_{i} \widetilde{V R}_{t-i}+\beta \cdot \sigma_{u, t}+\varepsilon_{t}
$$

Results are shown in Table 3, Unexpected volatility is found to be highly significant, and we obtain a good specification as measured by the LjungBox statistics, as far as we include enough lags of the variance ratio itself and $q$ is large enough. Thus, it is evident that unexpected volatility plays a crucial role in the emergence of intraday serial correlations, for all the considered time scales.

Most importantly, our results can be reconciled with the results in LeBaron 1992). To show this, we estimate the encompassing regression:

$$
\widetilde{V R}_{t}=\alpha+\sum_{i=1}^{4} \delta_{i} \widetilde{V R}_{t-i}+\beta \cdot \sigma_{p, t}+\gamma \cdot \sigma_{u, t}+\varepsilon_{t},
$$

where both unexpected and predictable volatility are included as regressors. Results are displayed in Table 4 and indicate that, while volatility has been found to be significant in model $\mathbf{7}$, its predictable part is negatively 
related with intraday variance ratios, and its unexpected part is positively related. Indeed, LeBaron (1992) did not use realized measures of intraday variance, but he filtered the variance with a GARCH-like model, thus he considered only the predictable part, getting a negative relation. Since we are using a realized measure of volatility, we can decompose it into a predictable and unpredictable part, and we consistently find that the first has a negative impact on intraday serial correlation, while the second has a large positive impact. A negative relation between predictable volatility and

intraday serial correlation could not be seen by Bianco and Renò (2006) in the Italian market, given the very low statistics (three years of data only). Thus, we conclude that unexpected volatility is the main source of intraday serial correlation, even if, at our knowledge, there is not an economic model explaining why the role of unexpected volatility is so important, since most economic models use total volatility.

\section{Conclusions}

In this paper we study the impact of volatility on intraday serial correlation in the US stock index futures market, which is the most liquid market in the world. We exploit the availability of intraday data to measure volatility by means of realized variance, and intraday serial correlation by means of standardized variance ratio. We find that, in agreement with the economic theory, total volatility plays a minor role in the US market, since the mechanism of reinforcement of opinions postulated by Chan (1993) is less important in this market. We then use our realized measure to decompose volatility into its predictable and unpredictable part, which we call unexpected volatility. We extend previous findings in the literature in the following direction. We find that there is a positive and significant relation between unexpected volatility and intraday serial correlation, while we confirm the LeBaron effect: predictable volatility is negatively related to serial correlation.

This result can be important for the economic theory, since this could potentially reveal basic properties about the pricing formation mechanism. As far as we know, there are no economic theories explaining the stylized fact documented by our study, thus our results introduce a new challenge. However, we presume that the role of unexpected volatility is linked to the way information is spread in the market. In this respect, unexpected volatil- 
ity could be potentially employed as a proxy for information asymmetry. Further research is needed to assess this conjecture.

\section{References}

Andersen, T., T. Bollerslev, and A. Das (2001). Variance-ratio statistics and high-frequency data: Testing for changes in intraday volatility patterns. Journal of Finance 56(1), 305-327.

Andersen, T., T. Bollerslev, F. Diebold, and P. Labys (2003). Modeling and forecasting realized volatility. Econometrica 71, 579-625.

Andersen, T., T. Bollerslev, and F. X. Diebold (2003). Parametric and nonparametric volatility measurement. In L. P. Hansen and Y. Ait-Sahalia (Eds.), Handbook of Financial Econometrics. Amsterdam: North-Holland.

Badrinath, S. G., J. R. Kale, and T. H. Noe (1995). Of shepherds, sheep, and the cross-autocorrelation in equity returns. Review of Financial Studies 8 , 401-430.

Bianco, S. and R. Renò (2006). Dynamics of intraday serial correlation in the Italian futures market. Journal of Futures Markets 26(1), 61-84.

Boudoukh, J., M. Richardson, and R. Whitelaw (1994). A tale of three schools: insights on autocorrelations of short-horizon stock. Review of financial studies 7(3), 539-573.

Cecchetti, S. G. and P. Sang Lam (1994). Variance-ratio tests: small-sample properties with an application to international output data. Journal of Business Economics and Statistics 12(2), 177-186.

Challet, D. and T. Galla (2005). Price return autocorrelation and predictability in agent-based models of financial markets. Quantitative Finance 5(6), 569-576.

Chan, K. (1993). Imperfect information and cross-autocorrelation among stock prices. Journal of Finance 48(4), 1211-1230.

Corsi, F., G. Zumbach, U. Muller, and M. Dacorogna (2001). Consistent high-precision volatility from high-frequency data. Economic Notes 30(2), 183-204. 
Cutler, D., J. Poterba, and L. Summers (1991). Speculative dynamics. $R e^{-}$ view of economic studies 58, 529-546.

Deo, R. S. and M. Richardson (2003). On the asymptotic power of the variance ratio test. Econometric Theory 19.

Fama, E. (1970). Efficient capital markets: a review of theory and empirical work. Journal of Finance 25, 383-417.

Faust, J. (1992). When are variance ratio tests for serial dependence optimal? Econometrica 60(5), 1215-1226.

Hansen, P. and A. Lunde (2005). A forecast comparison of volatility models: does anything beat a GARCH(1,1)? Journal of Applied Econometrics 20(7), 873-890.

James, J. (2003). Robustness of simple trend-following strategies. Quantitative Finance 3, 114-116.

Jegadeesh, N. and S. Titman (1993). Returns on buying winners and selling losers: implications for market efficiency. Journal of Finance 48, 65-91.

Kaul, A. and S. Sapp (2005). Trading activity and foreign exchange market quality. Working Paper.

LeBaron, B. (1992). Some relations between volatility and serial correlations in stock market returns. Journal of Business 65(2), 199-219.

Lo, A. W. and A. C. MacKinlay (1988). Stock market prices do not follow random walks: evidence from a simple specification test. Review of financial studies 1, 41-66.

Lo, A. W. and A. C. MacKinlay (1989). The size and the power of the variance ratio test in finite samples: a Monte Carlo investigation. Journal of Econometrics 40, 203-238.

Lo, A. W. and A. C. MacKinlay (1990). An econometric analysis of nonsynchronous trading. Journal of Econometrics 45, 181-211.

Maheu, J. and T. McCurdy (2002). Nonlinear features of realized FX volatility. Review of Economics and Statistics 84(3), 345-372.

Poon, S.-H. and C. Granger (2003). Forecasting volatility in financial markets: A review. Journal of Economic Literature 41(2), 478-539. 
Richardson, M. and T. Smith (1993). Test of financial models in the presence of overlapping observations. Review of Financial Studies 4(2), 227-254.

Safvenvblad (2000). Trading volume and autocorrelation: empirical evidence from the Stockholm Stock Exchange. Journal of Banking and Finance 24(8), 1275-1287.

Sentana, E. and S. Wadhwani (1992). Feedback traders and stock return autocorrelation: evidence from a century of daily data. Economic Journal 102, 415-425.

Shleifer, A. (2003). Inefficient Markets. Oxford University Press.

Thomas, S. and T. Patnaik (2003). Variance-ratio tests and high-frequency data: a study of liquidity and mean reversion in the indian equity markets. Working Paper. 


\section{A Variance Ratio asymptotic distribution}

Under the null hypothesis of random walk, the asymptotic distribution of the statistics (1) is the following. Define:

$$
\begin{array}{r}
\hat{\delta}_{k}=\frac{n q \sum_{j=k+1}^{n q}\left(P_{j}-P_{j-1}-\hat{\mu}\right)^{2}\left(P_{j-k}-P_{j-k-1}-\hat{\mu}\right)^{2}}{\left[\sum_{j=1}^{n q}\left(P_{j}-P_{j-1}-\hat{\mu}\right)^{2}\right]^{2}} \\
\hat{\theta}(q)=4 \sum_{k=1}^{q-1}\left(1-\frac{k}{q}\right)^{2} \hat{\delta}_{k} .
\end{array}
$$

Then we have:

$$
\sqrt{n q}(\widehat{V R}(q)-1) \sim N(0, \hat{\theta})
$$

The variance ratio test implemented here allows for heteroskedasticity, does not require the assumption of normality and in small samples it is more powerful than other tests, like the Ljung-Box statistics or the Dickey-Fuller unit root test, see Lo and MacKinlav (1989); Faust (1992); Cecchetti and Sang Lam (1994). 
all $\sigma^{2}, 100 \%$ of the sample

\begin{tabular}{|c|c|c|c|c|c|c|}
\hline$q$ & $90 \%^{+}$ & $90 \%^{-}$ & $95 \%^{+}$ & $95 \%^{-}$ & $99 \%^{+}$ & $99 \%^{-}$ \\
\hline 1 & 0.064 & 0.209 & 0.034 & 0.120 & 0.004 & 0.034 \\
\hline 2 & 0.057 & 0.202 & 0.029 & 0.103 & 0.005 & 0.021 \\
\hline 3 & 0.051 & 0.191 & 0.025 & 0.093 & 0.006 & 0.013 \\
\hline 4 & 0.047 & 0.173 & 0.024 & 0.065 & 0.006 & 0.003 \\
\hline 5 & 0.044 & 0.157 & 0.024 & 0.053 & 0.006 & 0.001 \\
\hline \multicolumn{7}{|c|}{$\sigma^{2}>3 \cdot 10^{-5}, 68.5 \%$ of the sample } \\
\hline$q$ & $90 \%^{+}$ & $90 \%^{-}$ & $95 \%^{+}$ & $95 \%^{-}$ & $99 \%^{+}$ & $99 \%^{-}$ \\
\hline 1 & 0.089 & 0.205 & 0.045 & 0.123 & 0.004 & 0.039 \\
\hline 2 & 0.069 & 0.201 & 0.031 & 0.109 & 0.007 & 0.024 \\
\hline 3 & 0.066 & 0.177 & 0.030 & 0.098 & 0.006 & 0.013 \\
\hline 4 & 0.055 & 0.161 & 0.030 & 0.072 & 0.007 & 0.001 \\
\hline 5 & 0.052 & 0.153 & 0.027 & 0.061 & 0.007 & 0.001 \\
\hline \multicolumn{7}{|c|}{$\sigma^{2}>7.5 \cdot 10^{-5}, 35.8 \%$ of the sample } \\
\hline$q$ & $90 \%^{+}$ & $90 \%^{-}$ & $95 \%^{+}$ & $95 \%^{-}$ & $99 \%^{+}$ & $99 \%^{-}$ \\
\hline 1 & 0.088 & 0.212 & 0.041 & 0.127 & 0.007 & 0.048 \\
\hline 2 & 0.059 & 0.213 & 0.027 & 0.113 & 0.007 & 0.021 \\
\hline 3 & 0.055 & 0.185 & 0.021 & 0.100 & 0.007 & 0.013 \\
\hline 4 & 0.042 & 0.154 & 0.025 & 0.068 & 0.007 & 0.001 \\
\hline 5 & 0.042 & 0.145 & 0.025 & 0.058 & 0.008 & 0.000 \\
\hline \multicolumn{7}{|c|}{$\sigma^{2}>1.4 \cdot 10^{-4}, 15.8 \%$ of the sample } \\
\hline$q$ & $90 \%^{+}$ & $90 \%^{-}$ & $95 \%^{+}$ & $95 \%^{-}$ & $99 \%^{+}$ & $99 \%^{-}$ \\
\hline 1 & 0.128 & 0.147 & 0.071 & 0.096 & 0.016 & 0.035 \\
\hline 2 & 0.093 & 0.183 & 0.045 & 0.096 & 0.013 & 0.022 \\
\hline 3 & 0.074 & 0.173 & 0.038 & 0.093 & 0.010 & 0.013 \\
\hline 4 & 0.061 & 0.138 & 0.035 & 0.067 & 0.010 & 0.003 \\
\hline 5 & 0.058 & 0.154 & 0.035 & 0.064 & 0.010 & 0.000 \\
\hline \multicolumn{7}{|c|}{$\sigma^{2}>2 \cdot 10^{-4}, 8.1 \%$ of the sample } \\
\hline$q$ & $90 \%^{+}$ & $90 \%^{-}$ & $95 \%^{+}$ & $95 \%^{-}$ & $99 \%^{+}$ & $99 \%^{-}$ \\
\hline 1 & 0.151 & 0.132 & 0.094 & 0.082 & 0.025 & 0.038 \\
\hline 2 & 0.119 & 0.164 & 0.069 & 0.101 & 0.013 & 0.019 \\
\hline 3 & 0.101 & 0.151 & 0.057 & 0.094 & 0.013 & 0.013 \\
\hline 4 & 0.069 & 0.132 & 0.038 & 0.069 & 0.013 & 0.006 \\
\hline 5 & 0.063 & 0.138 & 0.038 & 0.069 & 0.013 & 0.000 \\
\hline
\end{tabular}

Table 1: Percentage of significant positive and negative VR, for different significance levels (one-sided), on subsamples with growing daily volatility, see the top of each panel. 


\begin{tabular}{|c|c|c|c|c|c|c|c|}
\hline$q$ & $\alpha$ & $\log \left(\sigma^{2}\right)$ & $V R_{t-1}$ & $\overline{V R_{t-2}}$ & $V R_{t-3}$ & $\overline{V R_{t-4}}$ & Q(5) \\
\hline \multirow[t]{5}{*}{1} & $\begin{array}{c}0.512 \\
(1.982)^{*}\end{array}$ & $\begin{array}{c}0.088 \\
(3.389)^{* *}\end{array}$ & & & & & $201.88^{* *}$ \\
\hline & $\begin{array}{c}0.610 \\
(2.398)^{* *}\end{array}$ & $\begin{array}{c}0.092 \\
(3.575)^{* *}\end{array}$ & $\begin{array}{c}0.179 \\
(8.100)^{* *}\end{array}$ & & & & $67.66^{* *}$ \\
\hline & $\begin{array}{c}0.741 \\
(2.905)^{* *}\end{array}$ & $\begin{array}{c}0.102 \\
(3.975)^{* *}\end{array}$ & $\begin{array}{c}0.161 \\
(7.200)^{* *}\end{array}$ & $\begin{array}{c}0.100 \\
(4.464)^{* *}\end{array}$ & & & $37.73^{* *}$ \\
\hline & $\begin{array}{c}0.819 \\
(3.210)^{* *}\end{array}$ & $\begin{array}{c}0.108 \\
(4.196)^{* *}\end{array}$ & $\begin{array}{c}0.153 \\
(6.824)^{* *}\end{array}$ & $\begin{array}{c}0.086 \\
(3.808)^{* *}\end{array}$ & $\begin{array}{c}0.088 \\
(3.912)^{* *}\end{array}$ & & $18.30^{* *}$ \\
\hline & $\begin{array}{c}0.881 \\
(3.452)^{* *}\end{array}$ & $\begin{array}{c}0.112 \\
(4.380)^{* *}\end{array}$ & $\begin{array}{c}0.148 \\
(6.590)^{* *}\end{array}$ & $\begin{array}{c}0.082 \\
(3.611)^{* *}\end{array}$ & $\begin{array}{c}0.078 \\
(3.462)^{* *}\end{array}$ & $\begin{array}{c}0.068 \\
(3.014)^{* *}\end{array}$ & 6.89 \\
\hline \multirow[t]{5}{*}{2} & $\begin{array}{c}0.070 \\
(0.295)\end{array}$ & $\begin{array}{c}0.049 \\
(2.022)^{*}\end{array}$ & & & & & $120.56^{* *}$ \\
\hline & $\begin{array}{c}0.193 \\
(0.817)\end{array}$ & $\begin{array}{c}0.055 \\
(2.309)^{*}\end{array}$ & $\begin{array}{c}0.147 \\
(6.585)^{* *}\end{array}$ & & & & $43.73^{* *}$ \\
\hline & $\begin{array}{c}0.306 \\
(1.284)\end{array}$ & $\begin{array}{c}0.064 \\
(2.665)^{* *}\end{array}$ & $\begin{array}{c}0.136 \\
(6.065)^{* *}\end{array}$ & $\begin{array}{c}0.075 \\
(3.315)^{* *}\end{array}$ & & & $29.09^{* *}$ \\
\hline & $\begin{array}{c}0.445 \\
(1.859)^{*}\end{array}$ & $\begin{array}{c}0.074 \\
(3.108)^{* *}\end{array}$ & $\begin{array}{c}0.129 \\
(5.779)^{* *}\end{array}$ & $\begin{array}{c}0.062 \\
(2.741)^{* *}\end{array}$ & $\begin{array}{c}0.103 \\
(4.590)^{* *}\end{array}$ & & 4.67 \\
\hline & $\begin{array}{c}0.498 \\
(2.068)^{*}\end{array}$ & $\begin{array}{c}0.078 \\
(3.271)^{* *}\end{array}$ & $\begin{array}{c}0.125 \\
(5.578)^{* *}\end{array}$ & $\begin{array}{c}0.060 \\
(2.671)^{* *}\end{array}$ & $\begin{array}{c}0.098 \\
(4.338)^{* *}\end{array}$ & $\begin{array}{c}0.043 \\
(1.901)^{*}\end{array}$ & 0.97 \\
\hline \multirow[t]{5}{*}{3} & $\begin{array}{c}0.073 \\
(0.321)\end{array}$ & $\begin{array}{c}0.050 \\
(2.216)^{*}\end{array}$ & & & & & $62.86^{* *}$ \\
\hline & $\begin{array}{c}0.144 \\
(0.641)\end{array}$ & $\begin{array}{c}0.053 \\
(2.353)^{* *}\end{array}$ & $\begin{array}{c}0.102 \\
(4.559)^{* *}\end{array}$ & & & & $27.50^{* *}$ \\
\hline & $\begin{array}{c}0.210 \\
(0.923)\end{array}$ & $\begin{array}{c}0.058 \\
(2.547)^{* *}\end{array}$ & $\begin{array}{c}0.097 \\
(4.317)^{* *}\end{array}$ & $\begin{array}{c}0.050 \\
(2.235)^{*}\end{array}$ & & & $20.37^{* *}$ \\
\hline & $\begin{array}{c}0.312 \\
(1.370)\end{array}$ & $\begin{array}{c}0.065 \\
(2.865)^{* *}\end{array}$ & $\begin{array}{c}0.093 \\
(4.162)^{* *}\end{array}$ & $\begin{array}{c}0.043 \\
(1.911)^{*}\end{array}$ & $\begin{array}{c}0.083 \\
(3.676)^{* *}\end{array}$ & & 3.75 \\
\hline & $\begin{array}{c}0.351 \\
(1.529)\end{array}$ & $\begin{array}{c}0.068 \\
(2.981)^{* *}\end{array}$ & $\begin{array}{c}0.091 \\
(4.054)^{* *}\end{array}$ & $\begin{array}{c}0.043 \\
(1.898)^{*}\end{array}$ & $\begin{array}{c}0.080 \\
(3.551)^{* *}\end{array}$ & $\begin{array}{c}0.032 \\
(1.401)\end{array}$ & 1.15 \\
\hline \multirow[t]{5}{*}{4} & $\begin{array}{c}0.199 \\
(0.917) \\
\end{array}$ & $\begin{array}{c}0.063 \\
(2.881)^{* *} \\
\end{array}$ & & & & & $26.03^{* *}$ \\
\hline & $\begin{array}{c}0.225 \\
(1.040)\end{array}$ & $\begin{array}{c}0.063 \\
(2.902)^{* *}\end{array}$ & $\begin{array}{c}0.054 \\
(2.391)^{* *}\end{array}$ & & & & $15.13^{* *}$ \\
\hline & $\begin{array}{c}0.251 \\
(1.150) \\
\end{array}$ & $\begin{array}{c}0.065 \\
(2.961)^{* *} \\
\end{array}$ & $\begin{array}{c}0.052 \\
(2.323)^{*} \\
\end{array}$ & $\begin{array}{c}0.027 \\
(1.192) \\
\end{array}$ & & & $12.59^{*}$ \\
\hline & $\begin{array}{c}0.311 \\
(1.420)\end{array}$ & $\begin{array}{c}0.069 \\
(3.134)^{* *}\end{array}$ & $\begin{array}{c}0.051 \\
(2.266)^{*}\end{array}$ & $\begin{array}{c}0.024 \\
(1.076)\end{array}$ & $\begin{array}{c}0.056 \\
(2.469)^{* *}\end{array}$ & & 3.88 \\
\hline & $\begin{array}{c}0.340 \\
(1.541)\end{array}$ & $\begin{array}{c}0.071 \\
(3.215)^{* *}\end{array}$ & $\begin{array}{c}0.050 \\
(2.215)^{*}\end{array}$ & $\begin{array}{c}0.025 \\
(1.104) \\
\end{array}$ & $\begin{array}{c}0.055 \\
(2.419)^{* *} \\
\end{array}$ & $\begin{array}{c}0.025 \\
(1.117) \\
\end{array}$ & 1.62 \\
\hline \multirow[t]{5}{*}{5} & $\begin{array}{c}0.269 \\
(1.277)\end{array}$ & $\begin{array}{c}0.069 \\
(3.256)^{* *}\end{array}$ & & & & & 8.24 \\
\hline & $\begin{array}{c}0.272 \\
(1.287)\end{array}$ & $\begin{array}{c}0.069 \\
(3.251)^{* *}\end{array}$ & $\begin{array}{c}0.007 \\
(0.317)\end{array}$ & & & & 7.65 \\
\hline & $\begin{array}{c}0.272 \\
(1.284)\end{array}$ & $\begin{array}{c}0.069 \\
(3.237)^{* *}\end{array}$ & $\begin{array}{c}0.007 \\
(0.313)\end{array}$ & $\begin{array}{c}0.005 \\
(0.201)\end{array}$ & & & 7.55 \\
\hline & $\begin{array}{c}0.308 \\
(1.446)\end{array}$ & $\begin{array}{c}0.071 \\
(3.332)^{* *}\end{array}$ & $\begin{array}{c}0.007 \\
(0.315)\end{array}$ & $\begin{array}{c}0.004 \\
(0.194)\end{array}$ & $\begin{array}{c}0.036 \\
(1.586)\end{array}$ & & 3.26 \\
\hline & $\begin{array}{c}0.329 \\
(1.537)\end{array}$ & $\begin{array}{c}0.073 \\
(3.390)^{* *}\end{array}$ & $\begin{array}{c}0.006 \\
(0.284)\end{array}$ & $\begin{array}{c}0.006 \\
(0.252)\end{array}$ & $\begin{array}{c}0.036 \\
(1.588)\end{array}$ & $\begin{array}{c}0.020 \\
(0.892)\end{array}$ & 1.55 \\
\hline
\end{tabular}

Table 2: Estimates of model 7, for different values of $q .{ }^{*}$ indicates $95 \%$ of confidence level, ** $99 \%$ of confidence level. 


\begin{tabular}{|c|c|c|c|c|c|c|c|}
\hline$q$ & $\alpha$ & $\overline{\sigma_{u, t}}$ & $V R_{t-1}$ & $V R_{t-2}$ & $V R_{t-3}$ & $V R_{t-4}$ & $\mathrm{Q}(5)$ \\
\hline \multirow[t]{5}{*}{1} & $\begin{array}{c}-0.358 \\
(-14.982)^{* *}\end{array}$ & $\begin{array}{c}0.586 \\
(13.606)^{* *}\end{array}$ & & & & & $224.86^{* *}$ \\
\hline & $\begin{array}{c}-0.292 \\
(-11.837)^{* *}\end{array}$ & $\begin{array}{c}0.596 \\
(14.094)^{* *}\end{array}$ & $\begin{array}{c}0.185 \\
(8.742)^{* *}\end{array}$ & & & & $71.43^{* *}$ \\
\hline & $\begin{array}{c}-0.252 \\
(-9.979)^{* *}\end{array}$ & $\begin{array}{c}0.631 \\
(14.946)^{* *}\end{array}$ & $\begin{array}{c}0.161 \\
(7.590)^{* *}\end{array}$ & $\begin{array}{c}0.135 \\
(6.281)^{* *}\end{array}$ & & & $30.64^{* *}$ \\
\hline & $\begin{array}{c}-0.226 \\
(-8.760)^{* *}\end{array}$ & $\begin{array}{c}0.640 \\
(15.208)^{* *}\end{array}$ & $\begin{array}{c}0.153 \\
(7.178)^{* *}\end{array}$ & $\begin{array}{c}0.120 \\
(5.543)^{* *}\end{array}$ & $\begin{array}{c}0.097 \\
(4.543)^{* *}\end{array}$ & & $11.31^{* *}$ \\
\hline & $\begin{array}{c}-0.210 \\
(-7.999)^{* *} \\
\end{array}$ & $\begin{array}{c}0.640 \\
(15.247)^{* *} \\
\end{array}$ & $\begin{array}{c}0.148 \\
(6.938)^{* *} \\
\end{array}$ & $\begin{array}{c}0.115 \\
(5.325)^{* *} \\
\end{array}$ & $\begin{array}{c}0.087 \\
(4.065)^{* *} \\
\end{array}$ & $\begin{array}{c}0.065 \\
(3.063)^{* *} \\
\end{array}$ & 2.53 \\
\hline \multirow[t]{5}{*}{2} & $\begin{array}{c}-0.409 \\
(-18.646)^{* *}\end{array}$ & $\begin{array}{c}0.560 \\
(14.186)^{* *}\end{array}$ & & & & & $164.53^{* *}$ \\
\hline & $\begin{array}{c}-0.348 \\
(-14.925)^{* *}\end{array}$ & $\begin{array}{c}0.564 \\
(14.437)^{* *}\end{array}$ & $\begin{array}{c}0.148 \\
(6.983)^{* *}\end{array}$ & & & & $61.97^{* *}$ \\
\hline & $\begin{array}{c}-0.310 \\
(-12.705)^{* *}\end{array}$ & $\begin{array}{c}0.590 \\
(15.070)^{* *}\end{array}$ & $\begin{array}{c}0.132 \\
(6.215)^{* *}\end{array}$ & $\begin{array}{c}0.110 \\
(5.122)^{* *}\end{array}$ & & & $35.59^{* *}$ \\
\hline & $\begin{array}{c}-0.269 \\
(-10.682)^{* *}\end{array}$ & $\begin{array}{c}0.608 \\
(15.623)^{* *}\end{array}$ & $\begin{array}{c}0.124 \\
(5.850)^{* *}\end{array}$ & $\begin{array}{c}0.095 \\
(4.410)^{* *}\end{array}$ & $\begin{array}{c}0.124 \\
(5.826)^{* *}\end{array}$ & & 4.63 \\
\hline & $\begin{array}{c}-0.256 \\
(-9.892)^{* *} \\
\end{array}$ & $\begin{array}{c}0.609 \\
(15.651)^{* *} \\
\end{array}$ & $\begin{array}{c}0.120 \\
(5.630)^{* *} \\
\end{array}$ & $\begin{array}{c}0.093 \\
(4.313)^{* *} \\
\end{array}$ & $\begin{array}{c}0.118 \\
(5.527)^{* *} \\
\end{array}$ & $\begin{array}{c}0.044 \\
(2.065)^{*}\end{array}$ & 1.14 \\
\hline \multirow[t]{5}{*}{3} & $\begin{array}{c}-0.424 \\
(-20.462)^{* *}\end{array}$ & $\begin{array}{c}0.534 \\
(14.290)^{* *}\end{array}$ & & & & & $87.25^{* *}$ \\
\hline & $\begin{array}{c}-0.382 \\
(-16.962)^{* *}\end{array}$ & $\begin{array}{c}0.534 \\
(14.350)^{* *}\end{array}$ & $\begin{array}{c}0.099 \\
(4.660)^{* *}\end{array}$ & & & & $40.04^{* *}$ \\
\hline & $\begin{array}{c}-0.352 \\
(-14.707)^{* *}\end{array}$ & $\begin{array}{c}0.549 \\
(14.718)^{* *}\end{array}$ & $\begin{array}{c}0.091 \\
(4.274)^{* *}\end{array}$ & $\begin{array}{c}0.080 \\
(3.712)^{* *}\end{array}$ & & & $26.88^{* *}$ \\
\hline & $\begin{array}{c}-0.313 \\
(-12.508)^{* *}\end{array}$ & $\begin{array}{c}0.564 \\
(15.163)^{* *}\end{array}$ & $\begin{array}{c}0.087 \\
(4.068)^{* *}\end{array}$ & $\begin{array}{c}0.071 \\
(3.298)^{* *}\end{array}$ & $\begin{array}{c}0.104 \\
(4.888)^{* *}\end{array}$ & & 4.89 \\
\hline & $\begin{array}{c}-0.301 \\
(-11.562)^{* *}\end{array}$ & $\begin{array}{c}0.565 \\
(15.192)^{* *}\end{array}$ & $\begin{array}{c}0.084 \\
(3.932)^{* *}\end{array}$ & $\begin{array}{c}0.070 \\
(3.262)^{* *}\end{array}$ & $\begin{array}{c}0.101 \\
(4.721)^{* *}\end{array}$ & $\begin{array}{c}0.037 \\
(1.717)^{*}\end{array}$ & 1.35 \\
\hline \multirow[t]{5}{*}{4} & $\begin{array}{c}-0.422 \\
(-21.169)^{* *} \\
\end{array}$ & $\begin{array}{c}0.516 \\
(14.376)^{* *} \\
\end{array}$ & & & & & $35.29^{* *}$ \\
\hline & $\begin{array}{c}-0.401 \\
(-18.361)^{* *}\end{array}$ & $\begin{array}{c}0.515 \\
(14.356)^{* *}\end{array}$ & $\begin{array}{c}0.048 \\
(2.263)^{*}\end{array}$ & & & & $22.11^{* *}$ \\
\hline & $\begin{array}{c}-0.382 \\
(-16.262)^{* *}\end{array}$ & $\begin{array}{c}0.522 \\
(14.520)^{* *}\end{array}$ & $\begin{array}{c}0.046 \\
(2.136)^{*}\end{array}$ & $\begin{array}{c}0.050 \\
(2.314)^{*}\end{array}$ & & & $17.41^{* *}$ \\
\hline & $\begin{array}{c}-0.351 \\
(-14.100)^{* *}\end{array}$ & $\begin{array}{c}0.534 \\
(14.835)^{* *}\end{array}$ & $\begin{array}{c}0.044 \\
(2.054)^{*}\end{array}$ & $\begin{array}{c}0.046 \\
(2.157)^{*}\end{array}$ & $\begin{array}{c}0.079 \\
(3.672)^{* *}\end{array}$ & & 5.02 \\
\hline & $\begin{array}{c}-0.338 \\
(-12.967)^{* *}\end{array}$ & $\begin{array}{c}0.535 \\
(14.866)^{* *}\end{array}$ & $\begin{array}{c}0.042 \\
(1.980)^{*}\end{array}$ & $\begin{array}{c}0.047 \\
(2.169)^{*}\end{array}$ & $\begin{array}{c}0.077 \\
(3.597)^{* *}\end{array}$ & $\begin{array}{c}0.033 \\
(1.546)\end{array}$ & 1.31 \\
\hline \multirow[t]{5}{*}{5} & $\begin{array}{c}-0.413 \\
(-21.266)^{* *}\end{array}$ & $\begin{array}{c}0.494 \\
(14.127)^{* *}\end{array}$ & & & & & $11.39^{*}$ \\
\hline & $\begin{array}{c}-0.413 \\
(-19.335)^{* *}\end{array}$ & $\begin{array}{c}0.494 \\
(14.119)^{* *}\end{array}$ & $\begin{array}{c}0.001 \\
(0.007)\end{array}$ & & & & $11.37^{*}$ \\
\hline & $\begin{array}{c}-0.403 \\
(-17.441)^{* *}\end{array}$ & $\begin{array}{c}0.497 \\
(14.166)^{* *}\end{array}$ & $\begin{array}{c}0.001 \\
(-0.004)\end{array}$ & $\begin{array}{c}0.024 \\
(1.136)\end{array}$ & & & 10.44 \\
\hline & $\begin{array}{c}-0.379 \\
(-15.327)^{* *}\end{array}$ & $\begin{array}{c}0.506 \\
(14.377)^{* *}\end{array}$ & $\begin{array}{c}0.001 \\
(-0.012)\end{array}$ & $\begin{array}{c}0.024 \\
(1.135)\end{array}$ & $\begin{array}{c}0.059 \\
(2.733)^{* *}\end{array}$ & & 3.69 \\
\hline & $\begin{array}{c}-0.367 \\
(-14.059)^{* *}\end{array}$ & $\begin{array}{c}0.507 \\
(14.398)^{* *}\end{array}$ & $\begin{array}{c}-0.001 \\
(-0.056)\end{array}$ & $\begin{array}{c}0.025 \\
(1.185)\end{array}$ & $\begin{array}{c}0.059 \\
(2.730)^{* *}\end{array}$ & $\begin{array}{c}0.029 \\
(1.340)\end{array}$ & 1.17 \\
\hline
\end{tabular}

Table 3: Estimates of model [8, for different values of $q .{ }^{*}$ indicates $95 \%$ of confidence level, ** $99 \%$ of confidence level. 


\begin{tabular}{|c|c|c|c|c|c|c|c|c|}
\hline$q$ & $\alpha$ & $\sigma_{p, t}$ & $\sigma_{u, t}$ & $V R_{t-1}$ & $V R_{t-2}$ & $V R_{t-3}$ & $V R_{t-4}$ & Q(5) \\
\hline \multirow[t]{5}{*}{1} & $\begin{array}{c}-2.002 \\
(-6.631)^{* *}\end{array}$ & $\begin{array}{c}-0.167 \\
(-5.462)^{* *}\end{array}$ & $\begin{array}{c}0.586 \\
(13.705)^{* *}\end{array}$ & & & & & $169.25^{* *}$ \\
\hline & $\begin{array}{c}-1.928 \\
(-6.506)^{* *}\end{array}$ & $\begin{array}{c}-0.166 \\
(-5.540)^{* *}\end{array}$ & $\begin{array}{c}0.596 \\
(14.200)^{* *}\end{array}$ & $\begin{array}{c}0.184 \\
(8.791)^{* *}\end{array}$ & & & & $45.00^{* * *}$ \\
\hline & $\begin{array}{c}-1.856 \\
(-6.320)^{* *}\end{array}$ & $\begin{array}{c}-0.163 \\
(-5.483)^{* *} \\
\end{array}$ & $\begin{array}{c}0.631 \\
(15.043)^{* *} \\
\end{array}$ & $\begin{array}{c}0.161 \\
(7.647)^{* *}\end{array}$ & $\begin{array}{c}0.133 \\
(6.230)^{* *}\end{array}$ & & & $18.54^{* *}$ \\
\hline & $\begin{array}{c}-1.782 \\
(-6.084)^{* *}\end{array}$ & $\begin{array}{c}-0.158 \\
(-5.334)^{* *}\end{array}$ & $\begin{array}{c}0.639 \\
(15.292)^{* *}\end{array}$ & $\begin{array}{c}0.153 \\
(7.247)^{* *}\end{array}$ & $\begin{array}{c}0.118 \\
(5.521)^{* *}\end{array}$ & $\begin{array}{c}0.092 \\
(4.363)^{* *}\end{array}$ & & 8.04 \\
\hline & $\begin{array}{c}-1.710 \\
(-5.828)^{* *}\end{array}$ & $\begin{array}{c}-0.152 \\
(-5.134)^{* *}\end{array}$ & $\begin{array}{c}0.639 \\
(15.321)^{* *}\end{array}$ & $\begin{array}{c}0.149 \\
(7.026)^{* *}\end{array}$ & $\begin{array}{c}0.114 \\
(5.324)^{* *}\end{array}$ & $\begin{array}{c}0.084 \\
(3.938)^{* *}\end{array}$ & $\begin{array}{c}0.058 \\
(2.752)^{* *}\end{array}$ & 3.97 \\
\hline \multirow[t]{5}{*}{2} & $\begin{array}{c}-2.506 \\
(-9.113)^{* *}\end{array}$ & $\begin{array}{c}-0.213 \\
(-7.650)^{* *}\end{array}$ & $\begin{array}{c}0.560 \\
(14.392)^{* *}\end{array}$ & & & & & $95.20^{* *}$ \\
\hline & $\begin{array}{c}-2.371 \\
(-8.694)^{* *}\end{array}$ & $\begin{array}{c}-0.205 \\
(-7.443)^{* *}\end{array}$ & $\begin{array}{c}0.563 \\
(14.631)^{* *}\end{array}$ & $\begin{array}{c}0.141 \\
(6.758)^{* *}\end{array}$ & & & & $30.16^{* *}$ \\
\hline & $\begin{array}{c}-2.275 \\
(-8.365)^{* *} \\
\end{array}$ & $\begin{array}{c}-0.199 \\
(-7.254)^{* *}\end{array}$ & $\begin{array}{c}0.588 \\
(15.219)^{* *} \\
\end{array}$ & $\begin{array}{c}0.127 \\
(6.036)^{* *}\end{array}$ & $\begin{array}{c}0.103 \\
(4.849)^{* *}\end{array}$ & & & $20.96^{* *}$ \\
\hline & $\begin{array}{c}-2.148 \\
(-7.928)^{* *}\end{array}$ & $\begin{array}{c}-0.190 \\
(-6.965)^{* *}\end{array}$ & $\begin{array}{c}0.605 \\
(15.730)^{* *} \\
\end{array}$ & $\begin{array}{c}0.119 \\
(5.701)^{* *}\end{array}$ & $\begin{array}{c}0.089 \\
(4.192)^{* *}\end{array}$ & $\begin{array}{c}0.115 \\
(5.466)^{* *} \\
\end{array}$ & & 6.31 \\
\hline & $\begin{array}{c}-2.097 \\
(-7.693)^{* *}\end{array}$ & $\begin{array}{c}-0.186 \\
(-6.782)^{* *} \\
\end{array}$ & $\begin{array}{c}0.605 \\
(15.739)^{* *} \\
\end{array}$ & $\begin{array}{c}0.116 \\
(5.542)^{* *}\end{array}$ & $\begin{array}{c}0.088 \\
(4.130)^{* *}\end{array}$ & $\begin{array}{c}0.111 \\
(5.255)^{* *}\end{array}$ & $\begin{array}{c}0.031 \\
(1.458) \\
\end{array}$ & 6.59 \\
\hline \multirow[t]{5}{*}{3} & $\begin{array}{c}-2.365 \\
(-9.084)^{* *}\end{array}$ & $\begin{array}{c}-0.197 \\
(-7.477)^{* *}\end{array}$ & $\begin{array}{c}0.534 \\
(14.488)^{* *}\end{array}$ & & & & & $43.93^{* *}$ \\
\hline & $\begin{array}{c}-2.283 \\
(-8.785)^{* *}\end{array}$ & $\begin{array}{c}-0.193 \\
(-7.341)^{* *}\end{array}$ & $\begin{array}{c}0.534 \\
(14.542)^{* *}\end{array}$ & $\begin{array}{c}0.094 \\
(4.444)^{* *}\end{array}$ & & & & $16.33^{* *}$ \\
\hline & $\begin{array}{c}-2.219 \\
(-8.543)^{* *} \\
\end{array}$ & $\begin{array}{c}-0.189 \\
(-7.218)^{* *} \\
\end{array}$ & $\begin{array}{c}0.548 \\
(14.877)^{* *} \\
\end{array}$ & $\begin{array}{c}0.086 \\
(4.087)^{* *} \\
\end{array}$ & $\begin{array}{c}0.074 \\
(3.471)^{* *} \\
\end{array}$ & & & $14.10^{*}$ \\
\hline & $\begin{array}{c}-2.125 \\
(-8.199)^{* *} \\
\end{array}$ & $\begin{array}{c}-0.183 \\
(-7.023)^{* *}\end{array}$ & $\begin{array}{c}0.562 \\
(15.288)^{* *}\end{array}$ & $\begin{array}{c}0.082 \\
(3.898)^{* *} \\
\end{array}$ & $\begin{array}{c}0.065 \\
(3.087)^{* *} \\
\end{array}$ & $\begin{array}{c}0.097 \\
(4.600)^{* *}\end{array}$ & & 5.37 \\
\hline & $\begin{array}{c}-2.087 \\
(-8.005)^{* *}\end{array}$ & $\begin{array}{c}-0.180 \\
(-6.883)^{* *}\end{array}$ & $\begin{array}{c}0.562 \\
(15.296)^{* *}\end{array}$ & $\begin{array}{c}0.080 \\
(3.807)^{* *}\end{array}$ & $\begin{array}{c}0.065 \\
(3.071)^{* *}\end{array}$ & $\begin{array}{c}0.095 \\
(4.487)^{* *}\end{array}$ & $\begin{array}{c}0.025 \\
(1.177) \\
\end{array}$ & 5.33 \\
\hline \multirow[t]{5}{*}{4} & $\begin{array}{c}-2.086 \\
(-8.318)^{* *}\end{array}$ & $\begin{array}{c}-0.169 \\
(-6.657)^{* *}\end{array}$ & $\begin{array}{c}0.516 \\
(14.533)^{* *}\end{array}$ & & & & & $15.30^{* *}$ \\
\hline & $\begin{array}{c}-2.056 \\
(-8.191)^{* *}\end{array}$ & $\begin{array}{c}-0.168 \\
(-6.617)^{* *} \\
\end{array}$ & $\begin{array}{c}0.515 \\
(14.514)^{* *} \\
\end{array}$ & $\begin{array}{c}0.046 \\
(2.148)^{*}\end{array}$ & & & & 8.22 \\
\hline & $\begin{array}{c}-2.025 \\
(-8.062)^{* *}\end{array}$ & $\begin{array}{c}-0.166 \\
(-6.571)^{* *}\end{array}$ & $\begin{array}{c}0.522 \\
(14.664)^{* *}\end{array}$ & $\begin{array}{c}0.043 \\
(2.029)^{*}\end{array}$ & $\begin{array}{c}0.047 \\
(2.188)^{*}\end{array}$ & & & 8.49 \\
\hline & $\begin{array}{c}-1.972 \\
(-7.860)^{* *}\end{array}$ & $\begin{array}{c}-0.164 \\
(-6.494)^{* *}\end{array}$ & $\begin{array}{c}0.533 \\
(14.963)^{* *}\end{array}$ & $\begin{array}{c}0.041 \\
(1.951)^{*}\end{array}$ & $\begin{array}{c}0.043 \\
(2.038)^{*}\end{array}$ & $\begin{array}{c}0.075 \\
(3.536)^{* *}\end{array}$ & & 4.35 \\
\hline & $\begin{array}{c}-1.939 \\
(-7.696)^{* *}\end{array}$ & $\begin{array}{c}-0.162 \\
(-6.387)^{* *}\end{array}$ & $\begin{array}{c}0.534 \\
(14.975)^{* *}\end{array}$ & $\begin{array}{c}0.040 \\
(1.897)^{*}\end{array}$ & $\begin{array}{c}0.044 \\
(2.055)^{*}\end{array}$ & $\begin{array}{c}0.074 \\
(3.480)^{* *}\end{array}$ & $\begin{array}{c}0.025 \\
(1.162)\end{array}$ & 3.73 \\
\hline \multirow[t]{5}{*}{5} & $\begin{array}{c}-1.873 \\
(-7.648)^{* *}\end{array}$ & $\begin{array}{c}-0.148 \\
(-5.980)^{* *}\end{array}$ & $\begin{array}{c}0.494 \\
(14.251)^{* *}\end{array}$ & & & & & 4.70 \\
\hline & $\begin{array}{c}-1.874 \\
(-7.640)^{* *}\end{array}$ & $\begin{array}{c}-0.148 \\
(-5.979)^{* *}\end{array}$ & $\begin{array}{c}0.494 \\
(14.244)^{* *}\end{array}$ & $\begin{array}{c}-0.001 \\
(-0.054)\end{array}$ & & & & 4.75 \\
\hline & $\begin{array}{c}-1.861 \\
(-7.582)^{* *}\end{array}$ & $\begin{array}{c}-0.148 \\
(-5.968)^{* *}\end{array}$ & $\begin{array}{c}0.497 \\
(14.286)^{* *}\end{array}$ & $\begin{array}{c}-0.001 \\
(-0.064)\end{array}$ & $\begin{array}{c}0.023 \\
(1.082) \\
\end{array}$ & & & 5.54 \\
\hline & $\begin{array}{c}-1.830 \\
(-7.455)^{* *}\end{array}$ & $\begin{array}{c}-0.147 \\
(-5.942)^{* *}\end{array}$ & $\begin{array}{c}0.506 \\
(14.491)^{* *}\end{array}$ & $\begin{array}{c}-0.002 \\
(-0.072)\end{array}$ & $\begin{array}{c}0.023 \\
(1.081)\end{array}$ & $\begin{array}{c}0.057 \\
(2.681)^{* *}\end{array}$ & & 3.68 \\
\hline & $\begin{array}{c}-1.802 \\
(-7.319)^{* *}\end{array}$ & $\begin{array}{c}-0.145 \\
(-5.859)^{* *}\end{array}$ & $\begin{array}{c}0.506 \\
(14.499)^{* *}\end{array}$ & $\begin{array}{c}-0.002 \\
(-0.107)\end{array}$ & $\begin{array}{c}0.024 \\
(1.129) \\
\end{array}$ & $\begin{array}{c}0.057 \\
(2.679)^{* *} \\
\end{array}$ & $\begin{array}{c}0.023 \\
(1.066) \\
\end{array}$ & 3.44 \\
\hline
\end{tabular}

Table 4: Estimates of model [9], for different values of $q .{ }^{*}$ indicates $95 \%$ of confidence level, ** $99 \%$ of confidence level. 